\title{
INCLUSÃO EXCLUDENTE, ASSISTÊNCIA, EDUCAÇÃO E PATERNALISMO
}

\author{
EXCLUSIVE INCLUSION, ASSISTANCE TO THE NEEDY, EDUCATION AND \\ PATERNALISM
}

\author{
André Studart Leitão \\ Mestre e Doutor em Direito pela PUC-SP. Procurador Federal. Professor no Centro \\ Universitário Christus. Autor de direito previdenciário. \\ E-mail: andrestudart@hotmail.com. \\ Brenda Barros Freitas \\ Graduanda da Faculdade de Direito da Universidade Federal do Ceará. \\ E-mail: brenda.barrosf@yahoo.com.br.
}

Eduardo Rocha Dias

Professor do Programa de Pós-Graduação em Direito da Universidade de Fortaleza UNIFOR. Doutor em Direito. E-mail: eduardordias@ hotmail.com.

Recebido em: 12/09/2016

Aprovado em: 06/03/2017

Doi: $10.5585 / \mathrm{rdb} . v 17 \mathrm{i} 7.479$

RESUMO: O presente artigo pretende elaborar uma crítica ao modelo paternalista de Estado, tendo-se como referência sua função normalizadora. Qual deve ser o papel do Estado? Competelhe interferir no tecido social sob o pretexto de equilibrar as relações jurídicas e garantir o bemestar e a justiça social? Ou deve o Estado resignar-se com a ideia de invisibilidade? Sem nenhuma dúvida, a realidade atual brasileira alinha-se ao primeiro paradigma político. O Brasil é um Estado paternalista, cuja atuação materializa-se, sobretudo, através de prestações públicas assistenciais de natureza pecuniária e de mecanismos reversos de discriminação. De um lado, a renda decorrente de benefícios assistenciais estimula o mercado interno de consumo haja vista a maior circulação de capital. Por outro lado, o amparo estatal, além de comprometer considerável parcela do orçamento público, desestimula a busca pelo trabalho formal, elevando perigosamente a taxa de desocupação entre os jovens brasileiros. Também se questiona a efetividade do modelo educacional brasileiro e as políticas estatais de acesso ao ensino superior. Afinal, o paternalismo exagerado inclui ou exclui? Há necessidade de reavaliar os mecanismos protetivos de intervenção estatal? A contraposição entre os modelos intervencionista e liberal é imprescindível para a definição do arquétipo ideal, bem como para a análise da dicotomia entre as expressões "inclusão excludente" e "exclusão inclusiva", objetivo primordial do presente artigo.

Palavras-Chave: Paternalismo. Políticas públicas. Inclusão excludente. Estagnação.

ABSTRACT: This article attempts to carry out a critical analysis of the paternalistic state model, taking as reference the standard-setting role of the state. What should be the role of the state? Does its responsibility interferes with the social fabric under the guise of balancing the legal 
relationships and ensure the well-being and social justice? Or should the state be resigned with the idea of invisibility? Without any doubt, the current Brazilian state reality is closer to the first political paradigm. Brazil is a paternalistic state, whose performance materializes mainly through public welfare benefits of pecuniary nature and undeniable socioeconomic repercussions. Indeed, on the one hand, the income from welfare benefits stimulates domestic consumption due to the increased circulation of capital. On the other hand, state aid and benefits compromise considerable portion of the public budget, discourages the search for formal work, dangerously raising the unemployment rate among young Brazilians. The study also questions the effectiveness of the Brazilian education model and policies of acess to higher education. After all, excessive paternalism include or exclude? There is a need to re-evaluate the protective mechanisms of state intervention? The contrast between the interventionist and liberal models is essential to the ideal archetype definition as well as for the analysis of the dichotomy between the terms "exclusive inclusion" and "inclusive exclusion" primary objective of this article.

Keywords: Paternalism. Public policy. Exclusive inclusion. Stagnation.

SUMÁRIO: Introdução; 1. Paternalismo; 2. Assistencialismo; 3. Educação Disfuncional; Conclusão; Referências Bibliográficas.

\section{INTRODUÇÃO}

De forma geral, sobretudo após replicação global do modelo do Welfare State, consolidou-se o processo recorrente e universal de desenvolvimento de formas de proteção social aos componentes vulneráveis de cada sociedade, através de arquétipos rústicos ou de instituições especializadas e pluriprofissionais. Segundo Geraldo Di Giovanni ${ }^{1}$, os sistemas de proteção social decorrem de certas vicissitudes da vida natural ou social, tais como a velhice, a doença, o infortúnio e as privações em geral, estando incluídas, ainda, formas seletivas de distribuição e redistribuição de bens materiais, bens culturais - que permitirão a sobrevivência e a integração na vida social - e os princípios reguladores que, com objetivo protetivo, fazem parte da vida das coletividades.

Dentre as formas de manifestação de proteção social estão as políticas públicas, instrumentos para a realização de direitos, necessidades e potencialidades dos cidadãos. Basicamente, as políticas públicas visam, direta ou indiretamente, à redução das desigualdades sociais mediante mecanismos, espontâneos ou compulsórios, de redistribuição de riqueza. A tributação, principalmente a progressiva sobre os rendimentos, constitui outro meio de alcançar a redução da desigualdade, como destacado, mais recentemente, por Thomas Piketty, ao analisar o crescimento da desigualdade nos países por ele estudados após os anos setenta do século passado, sobretudo pela circunstância de o rendimento dos capitais superar o do trabalho ${ }^{2}$.

No Brasil, destacam-se as consequências socioeconômicas decorrentes dos programas sociais que integram as políticas públicas governamentais e revelam o modelo paternalista do Estado Brasileiro. Este estudo busca examinar alguns desses programas mantidos pelo Governo Federal: Bolsa Família (que inclui o Bolsa Escola, o Programa Nacional de Acesso à Alimentação, o Bolsa Alimentação e o Auxílio Gás), Bolsa Estiagem, Garantia-Safra e o Bolsa Qualificação Profissional. Em outra frente, o Governo Federal, mais uma vez sem nenhum planejamento, passou a investir no acesso da população ao ensino superior. Objetiva-se examinar neste artigo as regras de acesso e as consequências nem sempre desejadas desses programas, verificando se favorecem a inclusão ou se, ao contrário, perpetuam a exclusão. A metodologia

${ }^{1}$ GIOVANNI, Geraldo Di. Sistemas de proteção Social: uma introdução conceitual. In Reforma do Estado. Políticas de Emprego no Brasil. Campinas, UNICAMP, IE, 1998.

${ }^{2}$ PIKETTY, Thomas. O Capital no século XXI. Rio de Janeiro: Intrínseca, 2014, p. 480 e seguintes. 
empregada é qualitativa, baseada na análise de documentos, dados disponíveis em sítios de consulta pública e na bibliografia especializada.

\section{PATERNALISMO}

Originado da palavra latina "pater", que significa pai, paternalismo consiste no desenvolvimento de comportamentos que são típicos de um pai tradicional, só que aplicados outra modalidade de vínculo, como o laborativo e o político. Na relação entre o Estado e os cidadãos, o paternalismo implica intervencionismo excessivo, modo de exercício da autoridade, que trata de variados aspectos individuais e coletivos, sempre com o propósito de proteger a qualquer custo e de institucionalizar o controle governamental por dependência social.

No pensamento liberal, a crítica ao paternalismo é associada à obra de John Stuart Mill, para quem cada um deve ter a liberdade de definir seu próprio comportamento, ainda que isso lhe cause danos. Funda-se tal concepção na incerteza sobre o que é a verdade, no caráter educativo do erro e no ponto de vista de que somente o indivíduo pode aferir seu próprio bem-estar ${ }^{3}$. Admitem-se exceções, como é o caso das crianças e pessoas desprovidas da capacidade de tomar suas próprias decisões, e, de forma mais controvertida, quando as ações individuais causam danos a outras pessoas. O paternalismo pode se manifestar em relações entre iguais, como entre amigos, por exemplo, e em relações assimétricas, como entre patrões e empregados e entre indivíduos e o Estado.

Bobbio, citando Kant, refere-se à liberdade entendida como autonomia, ou seja, como capacidade de legislar para si próprio conforme uma lei universal racional, como a antítese de todo poder paterno ou patriarcal". Em oposição a um "Estado eudemonista", que inclui entre suas tarefas a busca da felicidade dos súditos, defende a atribuição a estes de tanta liberdade quanto baste à busca de sua própria felicidade. É evidente, porém, que tal formulação, excessivamente liberal e individualista, há de ser tomada na atualidade cum granum salis. O Estado deve assegurar aos cidadãos, mais do que uma formal e abstrata liberdade de agir, um mínimo material indispensável à subsistência e também o conhecimento necessário ao adequado exercício de sua liberdade. Ou seja, não há liberdade de escolha sem uma arquitetura institucional própria, que assegure acesso à informação, ausência de custos desproporcionais e excessivos vinculados à adoção de preferências diferentes e capacidade de julgar criticamente as próprias preferências ${ }^{5}$. O papel da educação na formação desse senso crítico é fundamental. A aversão de Kant a um Estado paternalista, por outro lado, é bem resumida na seguinte transcrição efetuada por Bobbio:

Um governo fundado no princípio da benevolência para com o povo, como é o caso do governo de um pai em face dos filhos, ou seja, um governo paternalista (imperium paternale), no qual os súditos, como filhos menores que não podem distinguir entre o que lhes é útil ou prejudicial, são obrigados a se comportar passivamente, para esperar que o chefe do Estado julgue de que modo eles devem ser felizes, esse governo é o pior despotismo que se pode imaginar ${ }^{6}$.

Nela se encontra, em primeiro lugar, uma adequada definição do Estado paternalista: é aquele cujos "súditos são considerados como eternos menores, ou seja, não como cidadãos ativos,

\footnotetext{
${ }^{3}$ MIGUEL, Luis Felipe. Autonomia, paternalismo e dominação na formação das preferências. Opinião Pública, Campinas, Vol. 21, no 3, dezembro de 2015, p. 609.

${ }^{4}$ BOBBIO, Norberto. A Era dos Direitos. Rio de Janeiro: Campus, 1992, p. 86 e também 89-90.

${ }^{5}$ MIGUEL, Luis Felipe. Autonomia, paternalismo e dominação na formação das preferências. Opinião Pública, Campinas, Vol. 21, n 3, dezembro de 2015, p. 607.

${ }^{6}$ BOBBIO, Norberto. A Era dos Direitos. Rio de Janeiro: Campus, 1992, p. 107.
}

Revista de Direito Brasileira | São Paulo, SP | v. 17 | n. 7 | p. 306 - 327 | Mai./Ago. 2017 
mas como súditos passivos"7 . Em segundo lugar, tem-se que a consequência de tal paternalismo é o despotismo, por privar a pessoa do direito à busca da própria felicidade. Daí o juízo radicalmente negativo de Kant acerca do Estado paternalista como "mau em si mesmo", a despeito das qualidades ou defeitos e das boas ou más intenções dos governantes .

Especificamente no Brasil, o paternalismo está presente desde a era colonial dominada pela escravatura. A propósito, colacione-se o pensamento de João José Reis e Eduardo Silva ${ }^{9}$, no sentido de que o caráter paternalista da época da escravidão era utilizado como forma de controle social.

[...] paternalismo, bem entendido, não significa relações escravistas harmoniosas e ausência de contradição; era estratégia de controle, meio de dominar de forma mais sutil e eficiente, com menos desgaste e alguma negociação. [...] Embora o termo 'paternalismo' possa ser 'muito amplo para uma análise minuciosa', como observa E. P. Thompson, paternalismo certamente descreve aspectos fundamentais da ideologia senhorial e das relações sociais entre a população escrava nacional e os senhores. Entenda-se por paternalismo, não concessão fácil, mas uma forma de controle mais eficaz do que o chicote do feitor. Thompson utiliza o termo no sentido gramsciano de hegemonia de classe, em que o dominado aceita o sistema desde que sejam respeitados certos direitos e privilégios, e também que seja possível a barganha. Em troca ele reconhece ter deveres a cumprir. As cartas de alforria, por exemplo, estão cheias de expressões em que os senhores invocam a imagem do pai, ou da mãe, para se referirem a suas relações com os escravos alforriados. E estes eram obrigados a zelar pelos ex-senhores como se fossem bons filhos. ${ }^{10}$

Mais recentemente, pode-se referir o "autoritarismo instrumental" que marcou o pensamento político brasileiro durante muito tempo no século $\mathrm{XX}$, segundo o qual a imaturidade do povo brasileiro justificaria a adoção de medidas autoritárias até que chegasse um momento, indeterminado, em que ele seria capaz de se autogovernar ${ }^{11}$. Tratando-se de forma de exercício do poder presente na sociedade brasileira há muito tempo, compreende-se o modelo paternalista adotado pelos gestores públicos, independentemente de planejamento e de um estudo socioeconômico consistente.

\section{ASSISTENCIALISMO}

O Brasil conta com uma rede de proteção social com enorme variedade de programas, sobretudo quando consideradas todas as esferas de Poder (federal, estadual e municipal). Silva, Yazbek e Giovanni salientam que a maioria dos programas está associada às exigências de contrapartida no campo da educação, da saúde e do trabalho ${ }^{12}$.

A Lei $\mathrm{n}^{\circ}$. 10.836 de 9 de janeiro de 2004, responsável pela conversão da Medida Provisória $n^{\circ}$. 132, de 2003, instituiu o Programa Bolsa Família, mediante a conglobação de

\footnotetext{
${ }^{7}$ BOBBIO, Norberto. Direito e Estado no Pensamento de Emanuel Kant. Brasília: Editora da Universidade de Brasília, 1992, p. 139.

${ }^{8}$ BOBBIO, Norberto. Direito e Estado no Pensamento de Emanuel Kant. Brasília: Editora da Universidade de Brasília, 1992, p. 139-140.

${ }^{9}$ REIS, João José e SILVA, Eduardo. Negociação e conflito: a resistência negra no Brasil escravista. São Paulo: Editora Schwarcz, 1989.

${ }^{10}$ Página 45 e 102.

${ }^{11}$ MIGUEL, Luis Felipe. Autonomia, paternalismo e dominação na formação das preferências. Opinião Pública, Campinas, Vol. 21, no 3, dezembro de 2015, p. 605.

12 SILVA, M. O. da S.; YASBEK, M. C.; GIOVANNI, G. di. A Política Social Brasileira no Século XXI: a prevalência dos programas de transferência de renda. São Paulo: Cortez, 2004, página 48.
} 
outros programas sociais $^{13}$, através de um único registro (Cadastro Único para Programas Sociais do Governo Federal). Com isso, valores antes recebidos separadamente passaram a ser pagos em parcela única. Atualmente vinculado ao Ministério do Desenvolvimento Social e Agrário (MDSA), o Bolsa Família possui diversas modalidades de benefícios pecuniários que variam de acordo com a composição e a renda familiar. São eles: o benefício básico (R \$77,00); os benefícios variáveis vinculados à criança ou ao adolescente de 0 a 15 anos (R $\$ 35,00)$, à gestante ( $\mathrm{R} \$ 35,00)$, ao adolescente (todos pagos às famílias com renda mensal de até $\mathrm{R} \$ 154,00$ ); e o benefício para superação da extrema pobreza, valor calculado individualmente para cada família a fim de garantir que renda por pessoa ultrapasse o piso de $\mathrm{R} \$ 77,00^{14}$.

Agricultores familiares residentes em municípios em situação de emergência ou de calamidade pública também são beneficiários do Bolsa Estiagem, que lhes garante um auxílio financeiro de $\mathrm{R} \$ 80,00$ mensais, pago por meio do cartão de pagamento do Bolsa Família ou do Cartão Cidadão ${ }^{15}$.

A Lei ${ }^{\circ} 10.420$, de 10 de abril de 2002, instituiu o Garantia-Safra ${ }^{16}$, com o escopo de garantir condições mínimas de sobrevivência aos agricultores familiares de Municípios sistematicamente sujeitos a perda de safra por estiagem ou excesso hídrico, situados na área de atuação da Superintendência do Desenvolvimento do Nordeste - SUDENE.

Instituído pela Medida Provisória no. 2.164-41, de 24 de agosto de 2001, o Bolsa Qualificação Profissional consiste em política destinada a subvencionar os trabalhadores que estejam com o contrato de trabalho suspenso, em conformidade com o disposto em convenção ou acordo coletivo de trabalho, matriculado em curso ou programa de qualificação profissional oferecido pelo empregador. Trata-se, portanto, de alternativa à demissão do trabalhador formal, em momentos de retração da atividade econômica que causa impactos ao mercado de trabalho, devido à possibilidade de uso do benefício de seguro-desemprego como Bolsa Qualificação Profissional para trabalhadores com contrato de trabalho suspenso ${ }^{17}$.

Para ser beneficiário de um ou mais programas que compõem a rede de proteção social no Brasil, o cidadão precisa estar inscrito no Cadastro Único para Programas Sociais do Governo Federal, instrumento, regulamentado pelo Decreto $n^{\circ}$. 6.135/07, responsável pela identificação e caracterização das famílias de baixa renda com a coleta de dados que incluem, por exemplo, características da residência, identificação de cada pessoa, escolaridade, situação de trabalho e renda. A responsabilidade pela execução do Cadastro Único é compartilhada entre o governo federal, os estados, os municípios e o Distrito Federal. O MDSA é o gestor responsável a nível federal, tendo a Caixa Econômica Federal como agente mantenedor do Sistema de Cadastro Único $^{18}$.

Para Silva, Yazbek e Giovanni, no Brasil, o desenvolvimento de programas sociais de transferência de renda é inspirado em duas formas de orientação político-ideológica. A primeira delas é a transferência de renda como programa compensatório residual pautado na ideia de que o desemprego e a exclusão social são inevitáveis. Objetiva garantir ao indivíduo a qualidade de consumidor e tem como orientação principal a pobreza extrema. Provoca a reprodução de uma classe de pobres, com garantia de sobrevivência no limiar da miséria. A segunda consiste na transferência de renda por meio de programas sociais, com fundamento no princípio

\footnotetext{
${ }^{13}$ Citam-se como exemplos os seguintes programas: renda mínima, programa nacional de acesso à alimentação e auxílio-gás.

$14 \quad$ Disponível em: <http://mds.gov.br/assuntos/bolsa-familia/o-que-e/beneficios/beneficios>

e $<\mathrm{http}: / /$ calendariobolsafamilia2015.com.br/bolsa-familia-2016/>. Acesso em 10/03/2016.

${ }^{15}$ Disponível em: <http://www.brasil.gov.br/observatoriodaseca/bolsa-estiagem.html>. Acesso em 10/03/2016.

16 Disponível em: <http://www.mda.gov.br/sitemda/secretaria/saf-garantia/sobre-o-programa>. Acesso em 10/03/2016.

17 Disponível em: 〈http://www.mtps.gov.br/seguro-desemprego/modalidades/bolsa-qualificacao〉. Acesso em $10 / 03 / 2016$.

${ }^{18}$ Disponível em: <http://mds.gov.br/assuntos/cadastro-unico/o-que-e-e-para-que-serve>. Acesso em 10/03/2016.
}

Revista de Direito Brasileira | São Paulo, SP | v. 17 | n. 7 | p. 306 - 327 | Mai./Ago. 2017 
redistributivo e orientada pelo critério da cidadania universa ${ }^{19}$. Nos dois casos, a transferência de renda ajusta-se ao propósito apriorístico de inclusão social, seja para o cumprimento de metas e estabelecimentos de dados estatísticos que demonstram a redução da extrema pobreza, seja com o intuito de proporcionar o exercício pleno de cidadania.

Os índices constantes do Relatório divulgado pelo Programa das Nações Unidas para o Desenvolvimento - Pnud, sobre os resultados da primeira meta (erradicação da pobreza extrema e da fome) dos Objetivos de Desenvolvimento do Milênio - ODM, definidos pelas Nações Unidas no início dos anos 2000 demonstram que o Brasil, entre 1990 e 2012, erradicou a fome e reduziu de $25,5 \%$ para $3,5 \%$ as situações de pobreza extrema ${ }^{20}$. A política pública necessária para o alcance de referido índice não onera exageradamente o orçamento. Compromete cerca de $0,5 \%$ do PIB e alcança por volta de cinquenta milhões de pessoas, em onze milhões de domicílios, promovendo medidas ligadas à educação e à saúde que vão beneficiar as gerações futuras ${ }^{21}$.

Não há, portanto, como negar o avanço social conquistado pelo Brasil nos últimos anos, sobretudo em razão dos programas de transferência de renda. Sem embargo, o amparo estatal de natureza exclusivamente pecuniária, depois de um tempo, passa a funcionar como fator de exclusão social, pois estabelece a relação de dependência socioeconômica com o Estado. Não há suporte estatal que vise ao desenvolvimento econômico-financeiro do grupo familiar. A rede estatal não dispõe de mecanismos consistentes voltados à educação básica, à capacitação e à profissionalização dos destinatários da assistência estatal. Essa limitada postura estatal, certamente, objetiva sucessivas reconduções políticas e conduz ao comodismo, à estagnação social, à informalidade e à falsa sensação de que o poder público implementa políticas públicas de inclusão. Cite-se como exemplo o benefício básico do Bolsa Família, previsto no art. $2^{\circ}$ da Lei 10.836/04, destinado a famílias que se encontrem em situação de extrema pobreza. De acordo com o parágrafo $2^{\circ}$ do mesmo artigo, o benefício básico, de $\mathrm{R} \$ 58,00$ (cinquenta e oito reais) por mês, será concedido a famílias com renda mensal per capita de até $\mathrm{R} \$ 60,00$ (sessenta reais). De outro lado, o parágrafo 15 prescreve que o benefício corresponde ao montante necessário para que a soma da renda familiar mensal e dos benefícios financeiros supere o valor de $\mathrm{R} \$ 70,00$ (setenta reais) per capita. Ora, vincular a cessação do benefício de um benefício assistencial à superação de determinado patamar de renda não pode ser considerado um bom mecanismo de seletividade, pois impulsiona a desocupação e o trabalho informal, considerando o risco de obliteração do amparo público em virtude da percepção de renda formal. A propósito, para Célia Lessa Kerstenetzky, um forte motivo para o cumprimento das condicionalidades do Bolsa Família é o medo de perder o benefício, e não o ganho esperado em termos de capacitação das crianças $^{22}$.

Ademais, a exigência de comprovação da frequência escolar como pressuposto de concessão do Bolsa Família, prevista no art. $3^{\circ}$ da Lei 10.836/04, não pode ser levada a sério. Recentemente, o Ministério Público apurou irregularidades no valor de 2,5 bilhões de reais no

\footnotetext{
${ }^{19}$ SILVA, M. O. da S.; YASBEK, M. C.; GIOVANNI, G. di. A Política Social Brasileira no Século XXI: a prevalência dos programas de transferência de renda. São Paulo: Cortez, 2004, páginas 36 e 37.

20 Disponível em: <http://www.pnud.org.br/Docs/5_RelatorioNacionalAcompanhamentoODM.pdf>. Acesso em 20/03/2016.

${ }^{21}$ BOSCH, Mariano, MELGUIZO, Ángel e PAGÉS, Carmen. Melhores aposentadorias, melhores trabalhos - em direção à cobertura universal na América Latina e no Caribe. Banco Interamericano de Desenvolvimento, 2013. Disponível em: <http://publications.iadb.org/bitstream/handle/11319/462/Melhores\%20Aposentadorias\%20Melhores\%20Trabalhos. pdf;jsessionid=83355BD29B4DE016B4A7CF023E2668F9?sequence=4, p. 17>. Acesso em: 23/12/2014.

22 KERSTENETZKY,. Redistribuição e desenvolvimento? A Economia Política do Programa Bolsa Família. DADOS - Revista de Ciências Sociais. Rio de Janeiro. v. 52, n. 1, p. 70, 2009.

Revista de Direito Brasileira | São Paulo, SP | v. 17 | n. 7 | p. 306 - 327 | Mai./Ago. 2017
} 
pagamento do benefício entre 2013 e 2014. Constataram-se saques de pessoas falecidas, de funcionários públicos, donos de empresas e doadores para campanhas políticas ${ }^{23}$.

Antônio Maria da Silveira, em artigo escrito para a Revista Brasileira de Economia, ainda na década de 70, defendeu o atendimento do direito à existência como aliviamento da pobreza. Contudo, ressalvou a necessidade de uma decisão ou de um compromisso social para sua erradicação a longo prazo através de um programa governamental capaz de eliminar a pobreza na medida do crescimento da economia ${ }^{24}$.

No Brasil, durante anos, encobriram-se e manipularam-se relevantes dados socioeconômicos que conduziam à impressão de que o país respirava uma economia robusta e vigorosa. A título de ilustração, mencionem-se as estatísticas sobre empregabilidade. O Brasil encerrou o ano de 2014 com a menor taxa de desemprego registrada em sua história recente: incríveis $4,8 \%{ }^{25}$. Supreendentemente, para o ano de 2016, já se estima (ou subestima) uma taxa de desemprego da ordem de $10 \%^{26}$. Como isso é possível? Evidentemente, atribuiu-se à abrupta crise econômica o fardo de protagonizar o avanço do desemprego. Mas não foi o único. Segundo os dados oficiais do IBGE, há poucos meses, a cada 100 brasileiros em idade laborativa, 53 trabalhavam, três procuravam emprego e não encontravam, e 44 não trabalhavam e nem procuravam emprego. Considerando-se que o critério de medida do desemprego leva em consideração não o quantitativo das pessoas sem ocupação, mas das que efetivamente procuram emprego, há aproximadamente um ano, propalava-se a notícia de que quase todos os brasileiros tinham emprego. Na realidade, quase metade não tinha ${ }^{27}$.

Para Paulo Rabello de Castro, o modelo paternalista constrói a imagem de um governo grátis para parcela considerável da população. Ao cultivar a ilusão de prosperidade social sem nenhuma contrapartida dos destinatários, o Estado atua como um agente esterilizador e impeditivo do surgimento de novas oportunidades de virada para o avanço da economia brasileira $^{28}$. Sedimentou-se a miragem de que o governante é capaz de produzir benefícios coletivos sem qualquer custo para sociedade, ou seja, de que tudo que provenha do setor público é gratuito ${ }^{29}$.

Em primeiro lugar, direitos não nascem em árvores, ou seja, todo direito tem um custo. A questão referente ao custo dos direitos foi analisada com profundidade por Cass Sunstein e Stephen Holmes em "The cost of the rights", obra que foi objeto de análise em interessante artigo de Flávio Galdino ${ }^{30}$. Para ele, o senso comum formado no pensamento jurídico brasileiro em torno dos direitos funda-se na premissa equivocada de que existem direitos fundamentais cuja tutela por parte do Estado independe de qualquer ação positiva, e, portanto, de qualquer custo. Ao contrário, todos os direitos subjetivos públicos são positivos, e as prestações necessárias à efetivação desses direitos têm custos ${ }^{31}$.

\footnotetext{
${ }^{23}$ Disponível em: < http://www1.folha.uol.com.br/poder/2016/05/1776564-ministerio-publico-ve-irregularidades-der-25-bilhoes-no-bolsa-familia.shtml>. Acesso em 08/08/2016.

${ }^{24}$ SILVEIRA, Antônio Maria. Redistribuição de renda. R. Bras. Econ. Rio de Janeiro, 29 (2): 11-15, abril/jun. 1975.

25 Disponível em: <http://g1.globo.com/jornal-da-globo/noticia/2015/01/brasil-encerra-2014-com-menor-taxa-dedesemprego-ja-registrada.html>. Acesso em 06/12/2015.

${ }^{26}$ Disponível em:< http://exame.abril.com.br/economia/noticias/taxa-de-desemprego-no-brasil-deve-atingir-10-em2016>. Acesso em 06/12/2015.

Disponível

em:

$<$ http://www.istoe.com.br/colunas-e-

blogs/coluna/367223_DESEMPREGO+E+MANIPULACOES>. Acesso em 06/12/2015.

${ }^{28}$ CASTRO, Paulo Rabello de. O mito do governo grátis. Rio de Janeiro: Edições de Janeiro, 2014, p. 15.

${ }^{29}$ Página 18.

${ }^{30}$ GALDINO, Flávio. O custo dos direitos. Artigo integrante da obra: TORRES, Ricardo Lobo (org.). Legitimação dos direitos humanos. Rio de Janeiro: Renovar, 2002, p. 215.

${ }^{31}$ GALDINO, Flávio. O custo dos direitos. Artigo integrante da obra: TORRES, Ricardo Lobo (org.). Legitimação dos direitos humanos. Rio de Janeiro: Renovar, 2002, p. 215
}

Revista de Direito Brasileira | São Paulo, SP | v. 17 | n. 7 | p. 306 - 327 | Mai./Ago. 2017 
Pois bem, terceirizar esse encargo ao Estado e atribuir ao "dinheiro público" a responsabilidade de lastrear a manutenção dos programas desvela um pensamento leniente, medíocre e inconsequente, afinal, como salientado por Margaret Thatcher ${ }^{32}$, o Estado não tem fonte de dinheiro senão o dinheiro que as pessoas ganham por si mesmas e para si mesmas. $\mathrm{O}$ Estado não produz riqueza. Não existe "dinheiro público". Existe apenas "dinheiro do contribuinte". Com isso, quer-se dizer que alguém paga a conta desse projeto de poder.

A decisão do governo brasileiro de manter e expandir os programas sociais como pauta prioritária, aliada à corrupção endêmica que assola os três Poderes da República, obstaculiza o crescimento sustentável da economia brasileira. O governo, direta ou indiretamente, apropria-se do dinheiro dos outros para manter as medidas de repasse de verbas e uma política assistencialista pautada prioritariamente em benefícios e direitos com propósitos populistas ${ }^{33}$.

Em 2013, o Bolsa Família completou dez anos. Ao mesmo tempo em que comemorava a informação de que 1,69 milhões de beneficiários, o equivalente a 12\% das 13,8 milhões de família atendidas pelo programa até então, deixaram espontaneamente o programa, o Governo atestava a sua ineficiência administrativa. Primeiro porque $12 \%$ não pode ser considerado um dado estatístico favorável. Segundo porque o próprio Governo sequer sabia se a pífia evasão do programa tinha acontecido por conta do aumento da renda família ou pela diminuição do número de integrantes dos grupos familiares ${ }^{34}$. Simplesmente inacreditável.

Nos últimos anos, o Governo brasileiro também implementou medidas assistencialistas (pouco eficazes) no campo da educação. A priori, pode-se pensar que o investimento público na educação teria o propósito de ensejar a evasão progressiva dos programas de transferência de renda. Não foi o que aconteceu. Não é o que está acontecendo.

\section{EDUCAÇÃO DISFUNCIONAL}

Assistência social seletiva não significa indiferença estatal com a extrema pobreza. Ao contrário, defende-se a realização de investimentos que, ao invés de intensificarem a relação de dependência social, resgatem segmentos populacionais marginalizados através da educação e do trabalho.

A fórmula do crescimento é simples: sem prejuízo de medidas assistencialistas de caráter temporário aos mais vulneráveis, o Estado precisa investir na qualidade da educação infantil, do ensino fundamental e médio, sem atalhos ou miragens. Não é o que tem ocorrido no Brasil.

Dentro de uma sociedade a educação é essencial para conscientização dos indivíduos enquanto cidadãos transformadores da realidade que estão inseridos -, e consiste em elemento primordial na construção de um efetivo Estado democrático, no qual a participação do povo deve ir muito além do voto.

Sob essa perspectiva, o Escritório da Organização das Nações Unidas para Educação, a Ciência e a Cultura (UNESCO) realizou o Fórum Mundial de Educação 2015, na cidade de

\footnotetext{
${ }^{32}$ Disponível em: <https://youtu.be/WPrIGhyPSsE>. Acesso em 14/05/2016.

${ }^{33}$ Felizmente, parcela considerável da população já manifesta insatisfação com a destinação dos recursos públicos. Segundo dados da pesquisa nacional "Gestão Pública Demandada pelo Cidadão", setenta e sete por cento dos entrevistados em todo o Brasil considera que os investimentos em infraestrutura, como estradas e equipamentos para escolas e hospitais, são mais relevantes do que em programas sociais. O dado é relevante, mas demanda algumas considerações. (pesquisa realizada pelo Datafolha, entre os dias 19 e 21 de fevereiro de 2014, com 2.091 brasileiros de todas as faixas de renda e condição social, homens e mulheres de todas as idades, em 120 municípios, incluindo regiões metropolitanas, capitais e cidades do interior. Pesquisa Nacional Datafolha, realizada pelo Instituto Atlântico, constante no relatório de atividades de janeiro a maio de 2014. Disponível em: <http://acijs.com.br/blog/wpcontent/uploads/2014/06/RELAT\%C3\%93RIO-MBE-2014-JAN-MAIO.pdf>. Acesso em: 28/05/2016.

34 Disponível em: <http://oglobo.globo.com/brasil/bolsa-familia-mais-de-16-milhao-de-casas-abriram-mao-dobeneficio-8312947>. Acesso em 08/07/2016.
}

Revista de Direito Brasileira | São Paulo, SP | v. 17 | n. 7 | p. 306 - 327 | Mai./Ago. 2017 
Incheon, na Coreia do Sul, no qual foi aprovada a Declaração de Incheon. Este documento estabelece metas a serem cumpridas até o ano de 2030 pelos países, reconhecendo a educação como elemento-chave para alcance do pleno emprego e erradicação da pobreza. O texto relaciona educação e desenvolvimento, pautando-se "nos direitos humanos e na dignidade; na justiça social; na inclusão; na proteção; na diversidade cultural, linguística e étnica; e na responsabilidade e na prestação de contas compartilhadas" 35 .

Maria Méndez Rocasolano, em sua obra intitulada "El poder del conocimiento em tempos de crisis: la educación de ciudadanos frente al conocimiento de los individuos, revisión de la paideia Isocrática"36, assevera o caráter de direito fundamental da educação, enaltecendo-a como elementar ao desenvolvimento, à paz, à convivência pacífica e à estabilidade econômica e institucional de cada país e entre as nações. Defende, nesse sentido, ser ferramenta apta a banir abusos e desigualdades, destacando a necessidade da formação política dos cidadãos na construção de uma consciência social de transformação, nos termos que seguem:

Se busca que la población conozca que la soberanía popular establece que ellos son los señores del sistema y responsable del devenir del Estado. En este sentido, podemos aquí hablar de una exigencia democrática que se expresa a través de una transformación cultural donde los ciudadanos, asuman la conciencia de la dirección de la sociedad en la que viven. ${ }^{37}$

Em sentido diametralmente oposto, no Brasil tem perpetuado a opção política de amparo financeiro estatal desenfreado aos que se dizem vulneráveis sem a concomitante oferta de educação de qualidade, que, além de imprudente do ponto de vista orçamentário, pode conduzir à exclusão social, afinal, conforme já salientado, a proteção desregrada, criada a pretexto de incluir, eventualmente, é um fator decisivo de exclusão e um obstáculo (quase autofágico) à educação e ao trabalho formal.

Mas o pacote estatal de bondades tem ido muito além de programas sociais de transferência de renda. Nos últimos doze anos, por exemplo, o governo brasileiro, ao invés de insistir na qualidade da educação básica, sem nenhum planejamento, resolveu investir no acesso da população ao ensino universitário. Basicamente, valeu-se de três estratégias: a instituição do Programa Universidade para Todos (ProUni), o fortalecimento do financiamento estudantil e a consolidação do sistema de cotas como mecanismo de discriminação reversa.

Programa Universidade para Todos (ProUni): em 13 de janeiro de 2005, a Lei 11.096 instituiu o Programa Universidade para Todos - ProUni ${ }^{38}$, destinado à concessão de bolsas de estudo integrais e bolsas de estudo parciais de $50 \%$ (cinquenta por cento) ou de $25 \%$ (vinte e cinco por cento) para estudantes de cursos de graduação e sequenciais de formação específica, em instituições privadas de ensino superior, com ou sem fins lucrativos.

De acordo com o art. $2^{\circ}$, a bolsa destina-se: I - a estudante que tenha cursado o ensino médio completo em escola da rede pública ou em instituições privadas na condição de bolsista integral; II - a estudante portador de deficiência, nos termos da lei; III - a professor da rede pública de ensino, para os cursos de licenciatura, normal superior e pedagogia, destinados à

\footnotetext{
${ }^{35}$ Fórum Mundial de Educação 2015. Declaração de Incheon. Educação 2030: rumo a uma educação de qualidade inclusiva e equitativa e à educação ao longo da vida para todos. Disponível em: <http://unesdoc.unesco.org/images/0023/002331/233137POR.pdf〉. Acesso em 18/03/2017.

36 Disponível

Disponível em:

<https://www.academia.edu/7795265/EL_PODER_DEL_CONOCIMIENTO_EN_TIEMPOS_DE_CRISIS_LA_ED UCACI\%C3\%93N_DE_CIUDADANOS_FRENTE_AL_CONOCIMIENTO_DE_LOS_INDIVIDUOS_REVISI\%C 3\%93N_DE_LA_PAIDEIA_ISOCR\%C3\%81TICA〉. Acesso em 18/03/2017.

${ }_{38}^{37}$ p. 7.

38 Disponível em: <http://www.planalto.gov.br/ccivil_03/_ato2004-2006/2005/lei/L11096.htm>. Acesso em
} 26/07/2016.

Revista de Direito Brasileira | São Paulo, SP | v. 17 | n. 7 | p. 306 - 327 | Mai./Ago. 2017 
formação do magistério da educação básica, independentemente da renda. Para concorrer a uma bolsa, o estudante deve obter a nota mínima do Exame Nacional do Ensino Médio (Enem), na edição imediatamente anterior ao processo seletivo do ProUni. Deve, também, ter renda familiar de até três salários mínimos por pessoa. $\mathrm{O}$ estudante escolhe a modalidade de bolsa e até cinco opções de instituições de ensino superior, cursos, habilitações ou turnos dentre as disponíveis, conforme sua renda familiar per capita e sua adequação aos critérios do programa.

Financiamento estudantil (FIES): levantamento feito pelo Estadão, com base em informações do Portal da Transparência e em microdados do Censo da Educação Superior, mostra que o FIES, criado em 1999 para emprestar dinheiro para alunos cursarem faculdades particulares, teve uma explosão de contratos após mudanças promovidas em 2010, coincidentemente mesmo ano de eleição presidencial. Os juros caíram de 6,5\% para 3,4\% ao ano. Além disso, o financiamento passou a ser concedido a qualquer momento, a exigência de fiador foi relaxada, e o prazo de quitação, alongado ${ }^{39}$.

No que diz respeito ao ProUni e ao FIES, pode-se dizer que a decisão do Governo de facilitar o acesso de pessoas ao ensino superior, sem um consistente estudo de base, alimenta duas estatísticas aparentemente contraditórias: ao mesmo tempo em que eleva o número de graduandos e de graduados, também eleva o número de desempregados qualificados (pelo menos, formalmente).

O diploma universitário não é garantia de empregabilidade. No caso da China, por exemplo, uma das principais potências econômicas do século XXI, segundo um relatório do Ministério de Recursos Humanos e Seguridade Social do país, divulgado em 2013, aproximadamente cinquenta por cento dos universitários graduados não conseguiam se posicionar no mercado de trabalho. Essencialmente, indicaram-se duas razões fundamentais: além do arrefecimento do crescimento econômico do país, o mercado de trabalho chinês ainda não era capaz de absorver empregos de alta categoria ${ }^{40}$. Nos Estados Unidos, o cenário não é diferente. Uma pesquisa realizada pela Agência Accenture durante o ano de 2013 indicou que mais de $41 \%$ dos recém-graduados norte-americanos encontravam-se desiludidos, subempregados ou não estavam utilizando o conhecimento adquirido na universidade em seus empregos 41 .

Thomas Piketty, ao investigar a temática da desigualdade, destaca que o sistema educacional deve fornecer formações e qualificações no mesmo ritmo das necessidades tecnológicas, sob pena de condenar aqueles com mais baixas formações a perceber remunerações menores. Também concluiu que, tanto na França quanto nos Estados Unidos, ainda que por razões diversas, a elevação do nível educacional não impactou positivamente a desigualdade de renda no trabalho nem levou a uma maior mobilidade social ${ }^{42}$.

Retornando ao contexto brasileiro, tem-se, em primeiro lugar, que o ingresso em curso superior, sem o nível educacional adequado, compromete a qualidade do profissional graduado. Apenas para se ter ideia da gravidade do quadro, segundo o Indicador de Analfabetismo Funcional (Inaf), divulgado em 2012 pelo Instituto Paulo Montenegro (IPM) e pela ONG Ação Educativa, somente $62 \%$ dos universitários são classificadas como plenamente alfabetizados.

\footnotetext{
39 Disponível em: <http://sao-paulo.estadao.com.br/noticias/geral,gasto-com-fies-cresce-13-vezes-e-chega-a-r-13-4bi-mas-ritmo-de-matriculas-cai-imp-,1634714>. Acesso em 08/07/2016.

${ }^{40}$ Disponível em: <http://www1.folha.uol.com.br/mundo/2013/08/1321726-quase-50-dos-universitarios-graduadosna-china-estao-desempregados.shtml $>$. Acesso em 20/06/2016.

41 Disponível em: <https://newsroom.accenture.com/news/four-out-of-10-recent-college-grads-are-underemployednew-accenture-research-finds.htm>. Acesso em 08/08/2016.

42 PIKETTY, Thomas. O Capital no século XXI. Rio de Janeiro: Intrínseca, 2014, p. 297-298 e 471-472. No caso francês, tem-se que o aumento generalizado da escolaridade aumentou a competição entre trabalhadores cada vez mais bem formados, levando a uma baixa no valor das remunerações em razão do aumento de oferta de mão de obra qualificada. Nos Estados Unidos, o alto custo da educação superior levou a uma ampliação do fosso entre a remuneração dos que tem acesso a ela e os que não têm.
}

Revista de Direito Brasileira | São Paulo, SP | v. 17 | n. 7 | p. 306 - 327 | Mai./Ago. 2017 
Vale dizer: entre os estudantes do ensino superior, 38\% são analfabetos funcionais por não dominarem habilidades básicas de leitura e escrita ${ }^{43}$. Pesquisa conduzida pela Universidade Católica de Brasília divulgada em 2014 concluiu que mais de 50\% do grupo controle de 800 universitários sofriam com o analfabetismo funcional ${ }^{44}$. Aliás, certamente, essa deficiência de formação foi um dos fatores que levou a $\mathrm{OAB}$ a instituir o exame da Ordem como pressuposto obrigatório para o exercício da advocacia ${ }^{45}$. Inclusive, já existem propostas para estender igual exigência ao curso de Medicina ${ }^{46}$.

Pode-se argumentar que o acesso às bolsas do ProUni pauta-se na meritocracia, pois o sistema (Sisprouni) classifica os estudantes de acordo com as suas opções e o desempenho obtido no Enem, sem prejuízo de uma nota mínima estabelecida pelo Ministério da Educação. Ora, mede-se o conteúdo de um bolsista com base em critérios de classificação com concorrência restrita? Se a qualidade do ensino médio na rede pública é precária, ainda que o sistema preveja um sistema classificatório, não há garantia de qualidade dos estudantes selecionados.

Em segundo lugar, o crescimento desproporcional do FIES elevou consideravelmente o gasto público, extrapolando os limites estabelecidos nas leis orçamentárias. Em 2014, por exemplo, segundo dados do MEC/FNDE ${ }^{47}$, o orçamento previsto para o FIES era de R\$13 bilhões, mas os gastos chegaram a R $\$ 13,75$ bilhões no fim do ano. O Relatório de Gestão do Exercício de 2014, publicado pelo FNDE indica que o número de contratos formalizados saltou de 154.250 em 2011 para 732.243 em $2014^{48}$.

Ainda em 2015, veículos de informação noticiaram que o governo havia deixado de repassar às instituições de ensino 7,5 bilhões de reais do programa ${ }^{49}$. A crise econômica levou o Ministério da Educação a alterar unilateralmente as regras, restringindo $\mathrm{o}$ acesso ao financiamento e limitando o percentual de reajuste das mensalidades para 6,4 pontos. A opinião pública, veículo autêntico de expressão da participação popular no controle político, aliada à repercussão midiática, combaliram a já fragilizada imagem da então Presidente da República, o que levou o Governo a retratar-se parcialmente ${ }^{50}$. A volatilidade das decisões políticas e a sequência de transformações no FIES apenas ratificam o precário modelo de gestão pública pautado na utilização irresponsável do dinheiro dos contribuintes com propósitos escusos e eleitoreiros (governo grátis).

O fato é que gasto público vinculado ao FIES e ao ProUni, além de não ser sustentável a médio prazo, está sujeito à inadimplência dos beneficiários do programa. Segundo levantamento

\footnotetext{
${ }^{43}$ A UNESCO define analfabeto funcional como toda pessoa que sabe escrever seu próprio nome, assim como lê e escreve frases simples, efetua cálculos básicos, porém é incapaz de interpretar o que lê e de usar a leitura e a escrita em atividades cotidianas, impossibilitando seu desenvolvimento pessoal e profissional. Ou seja, o analfabeto funcional não consegue extrair o sentido das palavras, colocar ideias no papel por meio da escrita, nem fazer operações matemáticas mais elaboradas". Disponível em: <http://www.planetaeducacao.com.br/portal/impressao.asp?artigo=700>. Acesso em 20/07/2016.

44 Disponível em: <http://folhapolitica.jusbrasil.com.br/noticias/113329087/pesquisador-conclui-que-mais-dametade-dos-universitarios-brasileiros-sao-analfabetos-funcionais>. Acesso em 20/07/2016.

${ }^{45}$ Porém, é importante salientar que praticamente todos os países europeus exigem que o bacharel em Direito seja aprovado pelo conselho de classe ou, pelo menos, que se submeta a programas de treinamento.

${ }^{46} \mathrm{Na}$ verdade, apesar de ainda não existir o exame obrigatório na Medicina, cada vez mais, nos diversos campos de atuação da ciência médica, formações complementares tornaram-se uma exigência de mercado, a ponto de seleções públicas indicarem o título de especialista como pré-requisito para que o médico aprovado tome posse no cargo.

${ }^{47}$ Disponível em: <http://g1.globo.com/educacao/noticia/2015/07/gasto-do-governo-com-fies-em-2015-ja-soma-52do-orcamento-previsto.html>. Acesso em 11/07/2016.

48 Disponível em: <http://portal.mec.gov.br/index.php?option=com_docman\&view=download\&alias=17528-fiesrelatorio-gestao-pcoa-exercicio-2014-tcu\&category_slug=maio-2015-pdf\&Itemid=30192 >. Acesso em 11/07/2016.

49 Disponível em: <http://veja.abril.com.br/blog/radar-on-line/brasil/fies-governo-da-calote-bilionario-emuniversidades/>. Acesso em 11/07/2016.

50 Disponível em: <http://www.brasil.gov.br/educacao/2015/03/fies-renova-contratos-com-reajuste-acima-de-6-4>. Acesso em 11/07/2016.
} 
da Controladoria-Geral da União (CGU), divulgado pela Folha de São Paulo em janeiro de 2016, 47\% dos devedores do FIES em fase de pagamento para o governo federal estão inadimplentes, e a grande maioria, com parcelas atrasadas há mais de um ano ${ }^{51}$. Inclusive, existe no Facebook uma comunidade "Nós Não Vamos Pagar Nada - FIES" com aproximadamente sete mil membros. Enquanto isso, a educação infantil e o ensino fundamental e médio oferecidos em escolas públicas permanecem alimentando o pacto de mediocridade e a certeza de um sistema educacional fracassado.

O investimento público bilionário no ensino superior é discutível. Não existe razoabilidade em considerar o acesso à educação superior um direito social ou individual. Quando muito, trata-se de uma faculdade, uma opção estratégica do Governo para fomentar a ciência, a tecnologia, a pesquisa e a inovação. Aliás, é o que dispõe o parágrafo $5^{\circ}$ do art. 218 da $\mathrm{CF} / 88$ : "É facultado aos Estados e ao Distrito Federal vincular parcela de sua receita orçamentária a entidades públicas de fomento ao ensino e à pesquisa científica e tecnológica".

Além do mais, qual vem sendo o impacto social da medida? Por acaso, a taxa de desemprego diminuiu? Ao contrário, entre dezembro de 2014 e janeiro de 2016, o número de pessoas desempregadas que tinham 11 ou mais anos de estudo passou de 690 mil $(64,2 \%)$ para 1,2 milhão $(65,3 \%)^{52}$.

O sucateamento das universidades públicas e o histórico de greves de docentes e servidores $^{53}$ demonstram a inabilidade do poder público de administrar a instituições de ensino no país. Certamente, seria mais eficiente para a educação e econômico para a União o financiamento de bolsas de estudo em universidades privadas e a realização de investimentos em pesquisa científica e tecnológica mediante parcerias público-privadas e compartilhamento de experiências, sempre com o rigoroso acompanhamento dos órgãos de controle.

Some-se a isso outro elemento impressionante: segundo dados publicados pelo Governo Federal, no ano de 2010, um aluno universitário custava para os cofres públicos cinco vezes mais do que um estudante da educação básica $(\mathrm{R} \$ 14.763,00 \text { x R \$2.632,00 por ano })^{54}$. Apenas para se ter ideia do potencial multiplicador da realocação da verba pública, em 2012, conforme ranking publicado pela Folha de São Paulo, a Universidade Federal do Ceará contava com 22.690 alunos $^{55}$. Com essa verba, a União poderia oferecer educação básica de qualidade para aproximadamente 113 mil alunos ${ }^{56}$.

De outro lado, pode-se argumentar que as melhores universidades do país são públicas com base no Índice Geral de Cursos (IGC). O IGC é um indicador oficial que leva em

\footnotetext{
${ }^{51}$ Disponível em: <http://www1.folha.uol.com.br/educacao/2016/01/1727211-quase-metade-dos-devedores-atrasapagamento-do-fies.shtml >. Acesso em 11/07/2016.

52 Disponível em: <https://www.ecodebate.com.br/2016/03/18/o-aumento-do-desemprego-entre-as-pessoas-maisescolarizadas-artigo-de-jose-eustaquio-diniz-alves/>. Acesso em 21/07/2016.

${ }_{53}$ Entre 1980 e 2005, houve dezessete greves (uma média de 0,68 greves por ano). Em 2015, registrou-se a maior greve da história das universidades federais. Foram 139 dias, aproximadamente cinco meses. Disponível em: <http://g1.globo.com/educacao/noticia/2015/10/apos-5-meses-universidades-federais-encerram-greve-partir-destaterca.html>. Acesso em 16/07/2016.

${ }^{54}$ Disponível em: <http://www.brasil.gov.br/educacao/2010/03/aluno-universitario-custa-cinco-vezes-mais-que-umestudante-da-educacao-basica>. Acesso em 16/07/2016.

${ }_{55}$ Disponível em: <http://ruf.folha.uol.com.br/2013/perfil/universidade-federal-do-ceara-ufc-31836.shtml>. Acesso em 17/07/2016.

${ }^{56}$ Note-se que não existe óbice constitucional para a participação ativa da União na educação infantil e no ensino fundamental e médio. De acordo com o parágrafo $1^{\circ}$ do art. 211 da CF/88, a União organizará o sistema federal de ensino e o dos Territórios, financiará as instituições de ensino públicas federais e exercerá, em matéria educacional, função redistributiva e supletiva, de forma a garantir equalização de oportunidades educacionais e padrão mínimo de qualidade do ensino mediante assistência técnica e financeira aos demais entes federados. Os parágrafos $2^{\circ}$ e $3^{\circ}$ do mesmo artigo prescrevem a atuação prioritária dos Municípios na educação infantil, e dos Estados e do Distrito Federal, no ensino fundamental e médio. Finalmente, o parágrafo $4^{\circ}$ dispõe que, na organização de seus sistemas de ensino, a União, os Estados, o Distrito Federal e os Municípios definirão formas de colaboração, de modo a assegurar a universalização do ensino obrigatório.
}

Revista de Direito Brasileira | São Paulo, SP | v. 17 | n. 7 | p. 306 - 327 | Mai./Ago. 2017 
consideração diversas variáveis, que traduzem resultados da avaliação de desempenho de estudantes, infraestrutura e instalações, recursos didático-pedagógicos e corpo docente. Ora, partindo do pressuposto de que os atuais egressos das universidades públicas foram previamente escolhidos através de rigorosa seleção (vestibular ou exame nacional do ensino médio), está-se diante de grupos homogêneos e qualificados, o que favorece substancialmente a elevada pontuação das instituições públicas. Certamente, o bom desempenho do corpo discente nos exames de avaliação não decorre apenas do ensino ministrado nas salas de aulas das universidades públicas, vítimas de greves recorrentes.

Sistema de cotas: depois de tramitar durante aproximadamente treze anos no Congresso Nacional $^{57}$, em 29 de agosto de 2012, foi sancionada a Lei $12.711^{58}$, consolidando em âmbito federal o polêmico sistema de cotas. De acordo com o seu art. $1^{\circ}$, as instituições federais de educação superior vinculadas ao Ministério da Educação reservarão, em cada concurso seletivo para ingresso nos cursos de graduação, por curso e turno, no mínimo 50\% (cinquenta por cento) de suas vagas para estudantes que tenham cursado integralmente o ensino médio em escolas públicas. No preenchimento das vagas, $50 \%$ (cinquenta por cento) deverão ser reservados aos estudantes oriundos de famílias com renda igual ou inferior a 1,5 salário-mínimo (um saláriomínimo e meio) per capita.

O sistema de cotas foi criado inicialmente nos Estados Unidos no século passado durante a década de sessenta, com o escopo de amenizar desníveis socioeconômicos de natureza racial. Em junho de 2015, a Suprema Corte Americana decidiu que a cota racial para admissão de novos alunos nas universidades não viola o princípio de igualdade e, portanto, não é inconstitucional. Entendeu que se trata de uma ação afirmativa que favorece estudantes negros e latinos, com o objetivo de promover a diversidade no ensino superior ${ }^{59}$.

No Brasil, os mecanismos de discriminação reversa (ou positiva) no ensino superior surgiram aproximadamente uma década antes da Lei 12.711/2012. O Estado do Rio de Janeiro foi um dos precursores na implementação do sistema de cotas em universidades estaduais. As Leis Estaduais $n^{\circ} 3.524 / 00, n^{\circ} 3.708 / 01$ e $n^{\circ} 4.151 / 03$ estabeleciam, respectivamente, cota para alunos egressos da rede pública estadual, cota para as populações negra e parda e reserva de vagas para discentes portadores de deficiência ${ }^{60}$.

A Universidade de Brasília (UnB), valendo-se de sua autonomia didático-científica e administrativa assegurada constitucionalmente, foi a primeira universidade federal a implantar o sistema de cotas no vestibular. Através de decisão do Conselho de Ensino, Pesquisa e Extensão (CEPE), a UnB aprovou o Plano de Metas para Integração Étnica, Racial e Social, prevendo cota de $20 \%$ para candidatos negros de todas as graduações, ingresso de indígenas por meio de ações de cooperação com a Fundação Nacional do Índio (FUNAI) e para fortalecimento de atividades de apoio ao sistema local de escolas públicas ${ }^{61}$.

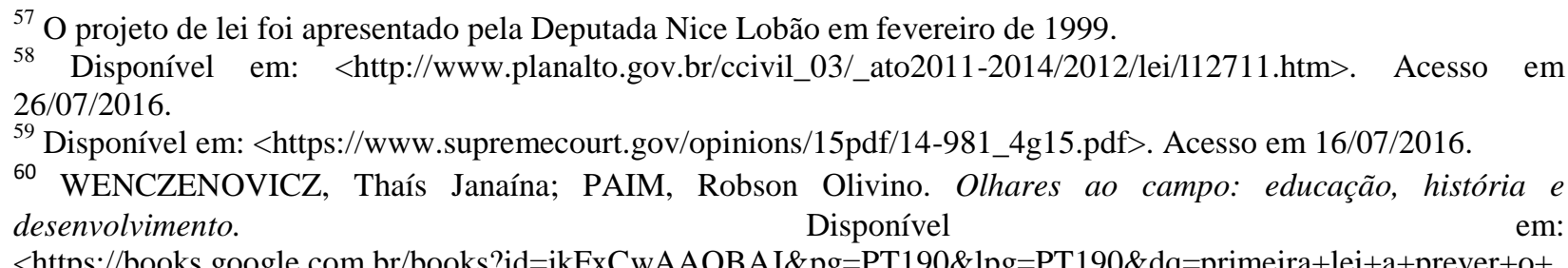
sistema+de+cotas+rio+de+janeiro\&source=bl\&ots=SPVTQJfvw5\&sig=wYq6dv6Gd5zHpvE3Fhrkh86C3t0\&hl=pt$\mathrm{BR} \& \mathrm{sa}=\mathrm{X} \& \mathrm{ved}=0 \mathrm{ahUKEwiDkeC9i \_ jNAhWKipAKHSduByYQ6AEIJDAB \# v=onepage \& q}=3.708 \& \mathrm{f}=$ false $>$. Acesso em 16/07/2016.

61 WENCZENOVICZ, Thaís Janaína; PAIM, Robson Olivino. Olhares ao campo: educação, história $e$ desenvolvimento. Disponível em: <https://books.google.com.br/books?id=jkFxCwAAQBAJ\&pg=PT190\&lpg=PT190\&dq=primeira+lei+a+prever+o+ sistema+de+cotas+rio+de+janeiro\&source=bl\&ots=SPVTQJfvw5\&sig=wYq6dv6Gd5zHpvE3Fhrkh86C3t0\&hl=pt $\mathrm{BR} \& \mathrm{sa}=\mathrm{X} \& \mathrm{ved}=0 \mathrm{ahUKEwiDkeC9i} \mathrm{j}$ NAhWKipAKHSduByYQ6AEIJDAB\#v=onepage $\& \mathrm{q}=3.708 \& \mathrm{f}=\mathrm{false}>$. Acesso em 16/07/2016. 
Contra tal implantação, em julho de 2009, o Partido Político Democratas (DEM) ajuizou arguição de descumprimento de preceito fundamental (ADPF 186) ${ }^{62}$. Em conclusão, o plenário do Supremo Tribunal Federal julgou improcedente o pedido com os seguintes fundamentos: $1^{\circ}$ ) não contraria - ao contrário, prestigia - o princípio da igualdade material, previsto no caput do art. $5^{\circ}$ da Carta da República, a possibilidade de o Estado lançar mão seja de políticas de cunho universalista, que abrangem um número indeterminados de indivíduos, mediante ações de natureza estrutural, seja de ações afirmativas, que atingem grupos sociais determinados, de maneira pontual, atribuindo a estes certas vantagens, por um tempo limitado, de modo a permitirlhes a superação de desigualdades decorrentes de situações históricas particulares; $2^{\circ}$ ) o modelo constitucional brasileiro incorporou diversos mecanismos institucionais para corrigir as distorções resultantes de uma aplicação puramente formal do princípio da igualdade; $3^{\circ}$ ) em diversos precedentes, o STF já havia assentado a constitucionalidade das políticas de ação afirmativa; $4^{\circ}$ ) medidas que buscam reverter, no âmbito universitário, o quadro histórico de desigualdade que caracteriza as relações étnico-raciais e sociais em nosso País, não podem ser examinadas apenas sob a ótica de sua compatibilidade com determinados preceitos constitucionais, isoladamente considerados, ou a partir da eventual vantagem de certos critérios sobre outros, devendo, ao revés, ser analisadas à luz do arcabouço principiológico sobre o qual se assenta o próprio Estado brasileiro; $5^{\circ}$ ) a metodologia de seleção diferenciada pode perfeitamente levar em consideração critérios étnico-raciais ou socioeconômicos, de modo a assegurar que a comunidade acadêmica e a própria sociedade sejam beneficiadas pelo pluralismo de ideias, de resto, um dos fundamentos do Estado brasileiro, conforme dispõe o art. $1^{\circ}, \mathrm{V}$, da Constituição; $6^{\circ}$ ) a Justiça social, hoje, mais do que simplesmente redistribuir riquezas criadas pelo esforço coletivo, significa distinguir, reconhecer e incorporar à sociedade mais ampla valores culturais diversificados, muitas vezes considerados inferiores àqueles reputados dominantes; $7^{\circ}$ ) por outro lado, o STF ressalvou que as políticas de ação afirmativa fundadas na discriminação reversa apenas são legítimas se a sua manutenção estiver condicionada à persistência, no tempo, do quadro de exclusão social que lhes deu origem. Caso contrário, tais políticas podem converter-se em benesses permanentes, instituídas em prol de determinado grupo social em detrimento da coletividade como um todo, situação - é escusado dizer - incompatível com o espírito de qualquer Constituição que se pretenda democrática, devendo, outrossim, respeitar a proporcionalidade entre os meios empregados e os fins perseguidos.

No campo acadêmico, Ronald Dworkin pondera que qualquer critério adotado coloca alguns candidatos em desvantagem diante dos outros, mas uma política de admissão pode, não obstante isso, justificar-se, caso pareça razoável esperar que o ganho geral da comunidade ultrapasse a perda global e caso não exista uma outra política que, não contendo uma desvantagem comparável, produza, ainda que aproximadamente, o mesmo ganho ${ }^{63}$.

Conquanto se trate de tema polêmico, não há como negar a existência de bons argumentos em favor do sistema de reserva de vagas pautado na descrição étnica (negros e pardos) e na higidez física (pessoas com deficiência) dos candidatos. Não se trata simplesmente de assegurar atalhos às universidades, corrigindo disfunções do ineficiente modelo da educação pública. Mecanismos de diversificação humana afiançam a tolerância, a aproximação das raças, a eliminação das diferenças, a incorporação de novos valores culturais e o fortalecimento do pluralismo. Ainda levam à criação de role models, personalidades simbólicas oriundas de grupos sociais discriminados que conquistaram sucesso pessoal e profissional e que, por isso, funcionam como modelo para gerações mais jovens ${ }^{64}$. Evidentemente, não basta simplesmente garantir o

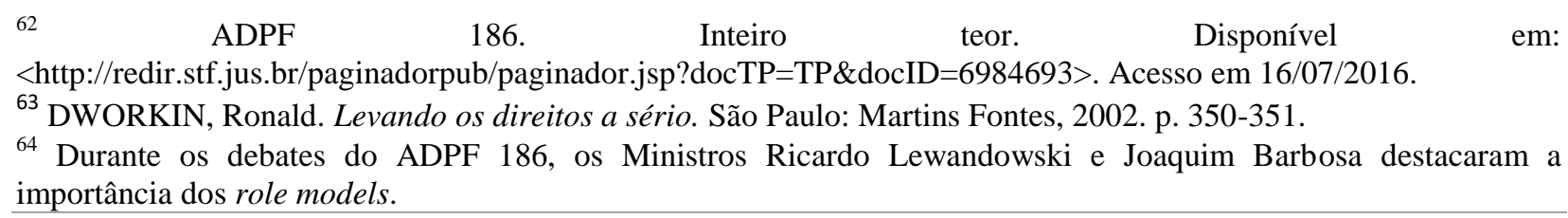

Revista de Direito Brasileira | São Paulo, SP | v. 17 | n. 7 | p. 306 - 327 | Mai./Ago. 2017 
acesso à universidade para negros, pardos e pessoas com deficiência. É fundamental que o poder público acompanhe o processo de formação universitária, através de suporte financeiro e de programas permanentes de escopo pedagógico ${ }^{65}$.

Por outro lado, o mesmo não se pode dizer em relação ao sistema de cotas para estudantes da rede pública. Nesse caso, a reserva de vagas é o atestado de incompetência do poder público na educação de base. A garantia de acessos diferenciados caracteriza medidas pontuais de abrangência subjetiva aleatória e que não interessam à coletividade.

Em rápidas palavras: $1^{\circ}$ ) o governo não investe na educação de base; $2^{\circ}$ ) porém, investe em programas permanentes de transferência de renda; $3^{\circ}$ ) porém, reserva parcela considerável das vagas em universidades federais para egressos de escolas públicas, distribuídas com base no perfil econômico dos candidatos; $4^{\circ}$ ) porém, concede bolsas de estudo integrais e parciais para estudantes que tenham cursado o ensino médio completo em escola da rede pública ou em instituições privadas na condição de bolsista integral, para estudantes com deficiência e para professores da rede pública de ensino; $5^{\circ}$ ) porém, financia de modo desregrado cursos de graduação para estudantes que se declaram hipossuficientes.

Uma solução alternativa para o país seria o investimento consistente e planejado na formação técnica. Pesquisa realizada pela empresa de consultoria e recrutamento Page Personnel revela que, mesmo com a economia em crise, a demanda por trabalhadores formados em sete cursos técnicos industriais subiu $15 \%$ durante o ano de $2015^{66}$.

Em 2011, no âmbito federal, foi editada a Lei $12.513^{67}$, instituindo o Programa Nacional de Acesso ao Ensino Técnico e Emprego (Pronatec), com os seguintes objetivos: I - expandir, interiorizar e democratizar a oferta de cursos de educação profissional técnica de nível médio presencial e a distância e de cursos e programas de formação inicial e continuada ou qualificação profissional; II - fomentar e apoiar a expansão da rede física de atendimento da educação profissional e tecnológica; III - contribuir para a melhoria da qualidade do ensino médio público, por meio da articulação com a educação profissional; IV - ampliar as oportunidades educacionais dos trabalhadores, por meio do incremento da formação e qualificação profissional; V estimular a difusão de recursos pedagógicos para apoiar a oferta de cursos de educação profissional e tecnológica. VI - estimular a articulação entre a política de educação profissional e tecnológica e as políticas de geração de trabalho, emprego e renda._O art. $2^{\circ}$ prevê atendimento prioritário para: I - estudantes do ensino médio da rede pública, inclusive da educação de jovens e adultos; II - trabalhadores; III - beneficiários dos programas federais de transferência de renda; e IV - estudante que tenha cursado o ensino médio completo em escola da rede pública ou em instituições privadas na condição de bolsista integral, nos termos do regulamento.

Não obstante a proposta seja interessante, mais uma vez, o Governo Federal implementou um programa sem nenhum planejamento. Segundo levantamento realizado pela Folha de São Paulo, em junho de 2014, a então Presidente da República afirmou que, até 2018, seriam abertas doze milhões de novas vagas. No ano seguinte, o programa sofreu corte, com previsão de oferta $57 \%$ menor em comparação a $2014^{68}$. Em reportagem publicada em julho de 2015, o Portal G1 noticiou a existência de professores do Pronatec em Minas Gerais que não recebiam salário havia oito meses ${ }^{69}$.

\footnotetext{
${ }^{65}$ Defendeu-se que a opção de a União investir no ensino universitário é equivocada. Porém, caso o Governo Federal mantenha a política, há fundamento para manutenção do sistema de cotas.

66 Disponível em: <http://www.portaldaindustria.com.br/cni/imprensa/2015/07/1,66364/cresce-demanda-porprofissionais-formados-em-cursos-tecnicos-industriais.html >. Acesso em 17/07/2016.

67 Disponível em: <http://www.planalto.gov.br/ccivil_03/_ato2011-2014/2011/lei/112513.htm>. Acesso em 26/07/2016.

68 Disponível em: <http://www1.folha.uol.com.br/educacao/2015/09/1677647-dilma-corta-metade-das-vagas-nopronatec-promessa-de-campanha.shtml>. Acesso em 17/07/2016.

69 Disponível em: <http://g1.globo.com/mg/centro-oeste/noticia/2015/07/professores-do-pronatec-estao-semremuneracao-ha-oito-meses-em-mg.html>. Acesso em 17/07/2016.
}

Revista de Direito Brasileira | São Paulo, SP | v. 17 | n. 7 | p. 306 - 327 | Mai./Ago. 2017 
Em setembro de 2015, o Ministério da Fazenda divulgou uma pesquisa demonstrando que, na maioria dos Estados e eixos tecnológicos, não existe diferença estatística significativa quanto à reinserção no mercado de trabalho formal entre o grupo de alunos e o grupo de controle. Ou seja: a conclusão do programa foi considerada irrelevante (ou pouco relevante) para fins de reinserção no mercado de trabalho. $O$ mesmo pôde ser verificado com relação aos ganhos salariais $^{70}$. Não bastasse isso, auditoria inédita da CGU no Pronatec, realizada em 2014, afirmou a impossibilidade de precisar o número de alunos que assistia de fato às aulas e como foram gastos os recursos repassados pelo Governo Federal. Apontou-se descontrole dos gastos públicos, pois não havia processo de prestação de contas nem análise e aprovação do cumprimento das vagas pactuadas com os ofertantes ${ }^{71}$.

E assim o Brasil caminha para a terceira década do século XXI com aproximadamente $27 \%$ de sua população composta por analfabetos (absolutos ou funcionais) ${ }^{72}$. Dentro do grupo das pessoas funcionalmente alfabetizadas (correspondente a $73 \%$ da população), a maioria (42\%) foi qualificada com o nível elementar (básico) e apenas $8 \%$ com o nível proficiente (avançado) ${ }^{73}$. Esse é o mapa da educação do Brasil, a pátria educadora.

Não há como deixar de considerar a necessidade de aprofundamento da pesquisa neste campo. Uma possível via a ser seguida se baseia na chamada abordagem das capacidades. Desenvolvida por autores como Amartya Sen e Martha Nussbaum, a abordagem das capacidades pretende estabelecer um novo enfoque sobre os chamados bens primários, os quais, para a teoria contratualista de John Rawls, constituiriam vantagens individuais necessárias para uma vida boa e uma sociedade mais justa ${ }^{74}$. Para Sen, tais capacidades permitiriam uma mensuração e comparação da qualidade de vida, enquanto para Nussbaum seriam um fundamento filosófico para definir garantias humanas centrais que "devem ser respeitadas e implementadas pelos governos de todas as nações, como um mínimo do que o respeito pela dignidade humana requer" ${ }^{\prime 75}$. Respeitando a liberdade individual, e considerando que é necessário reconhecer um mínimo para cada uma dessas capacidades, o que pode justificar a manutenção de programas de redistribuição de renda, que garantam um mínimo à subsistência, à educação, à saúde e ao acesso à propriedade ${ }^{76}$, tal abordagem não enseja o estabelecimento de um dever para o exercício de aludidas capacidades, mas o estabelecimento de condições que permitam às pessoas desenvolvêlas.

A lista de capacidades desenvolvida por Martha Nussbaum não é fechada ${ }^{77}$ nem definitiva, mas permite uma reflexão sobre o que o Estado deve assegurar de modo a permitir o

\footnotetext{
${ }^{70}$ Disponível em: <http://portal.mec.gov.br/index.php?option=com_docman\&view=download\&alias=22061 24092015-lancamento-estudos-pronatec-ministerio-fazenda-pdf\&category_slug=abril-2010-pdf\&Itemid=30192> . Acesso em 17/07/2016.

${ }^{71}$ Disponível em: <http://www1.folha.uol.com.br/poder/2014/10/1534748-auditoria-aponta-descontrole-em-vitrinede-dilma.shtml>. Acesso em 17/07/2016.

${ }^{72}$ Conforme indicador de Alfabetismo Funcional (Inaf) divulgado no Anuário Brasileiro da Educação Básica de 2016. Disponível em: <http://www.todospelaeducacao.org.br//arquivos/biblioteca/anuario_educacao_2016.pdf>. Acesso em 20/07/2016.

${ }^{73}$ Disponível em: 〈http://www.todospelaeducacao.org.br//arquivos/biblioteca/anuario_educacao_2016.pdf >. Acesso em 20/07/2016.

${ }^{74}$ SEN, Amartya. A ideia de justiça. São Paulo: Companhia das Letras, 2011, p. 265 e seguintes.

${ }^{75}$ NUSSBAUM, Martha. Fronteiras da justiça. São Paulo: Martins Fontes, 2013, p. 84.

76 Muito embora o critério da renda não possa ser considerado o único, podendo outros fatores também serem importantes, como o gênero, a existência de alguma incapacidade, dentre outras. Nesse sentido, SEN, Amartya. A ideia de justiça. São Paulo: Companhia das Letras, 2011, p. 294.

77 A lista compreende: 1) vida, ou a capacidade de viver até o fim uma vida humana normal, não morrer prematuramente ou reduzir as condições de vida de tal forma que não valha a pena ser vivida; 2) saúde física; 3 ) integridade física; 4) sentidos, imaginação e pensamento, o que inclui a educação, a liberdade de expressão e religiosa; 5) emoções, o que inclui a capacidade de desenvolver relações afetivas; 6) razão prática, que inclui a reflexão sobre o bem e a própria vida; 7) afiliação, que é viver com e para os outros, interagindo em sociedade, e ter bases de autorrespeito e não humilhação e não discriminação; 8) ser capaz de viver em harmonia com outras espécies

Revista de Direito Brasileira | São Paulo, SP | v. 17 | n. 7 | p. 306 - 327 | Mai./Ago. 2017
} 
desenvolvimento humano de forma sustentável e com respeito à dignidade da pessoa, evitando a perpetuação da dependência e da exclusão.

\section{CONCLUSÃO}

A estrutura do Estado paternalista brasileiro, pautada em programas assistenciais de transferência de renda e em um distorcido modelo de educação que privilegia o ensino superior em detrimento da educação básica, não promove a inclusão social.

A redistribuição de renda deve ser uma política permanente de Estado, mas não deve significar suporte pecuniário permanente para hipossuficientes. A simplória e limitada ação estatal de extrair capital da população produtiva e distribuir (ou seja, redistribuir) para os que se dizem vulneráveis, absolutamente, não é um mecanismo de geração de riqueza. Ao contrário, a pretexto de incluir segmentos marginalizados, o Estado promove a exclusão social, pois fortalece uma relação patológica de dependência socioeconômica que estimula a desocupação e o trabalho informal. É fundamental que o Estado formate políticas públicas capazes de gerar riqueza, e não simplesmente redistribuí-la.

No campo da educação, nos últimos anos, o Governo passou a investir bilhões de reais em programas de acesso ao ensino superior. Afinal, qual foi o impacto social da medida? A taxa de desemprego diminuiu? Ao contrário. Praticamente dobrou. Enquanto isso, parcela considerável da população brasileira é composta por analfabetos (absolutos ou funcionais). Não é no nível superior em que ocorrem as reais transformações sociais de que o Brasil tanto necessita. É na educação básica.

Além do mais, o progressivo investimento em programas sociais e educacionais não inclusivos, paradoxalmente, contribui para a redução da qualidade de vida de vários brasileiros que, direta ou indiretamente, lastreiam as generosas ações estatais através de uma tributação que beira a ideia de confisco.

O governo alcança resultados rasos, pois não implementa apoio no desenvolvimento socioeconômico dos favorecidos. Ao não lhes abrir a porta para as oportunidades, fideliza o ciclo da pobreza. Sob outro viés, ao lhes abrir a porta para o ensino superior, afiança a ilusão de que o diploma universitário resolverá o problema do desemprego. Não resolverá. Num país em que parcela considerável da população universitária é composta por analfabetos funcionais, um diploma de graduação não certifica qualificação, muito menos competência.

A experiência de investir em cursos técnicos também não foi exitosa no Brasil. O recéminstituído Pronatec já dá claros sinais de retração, com significativa redução do número de vagas e resultados decepcionantes.

É simplesmente inacreditável que o dinheiro público seja gasto tão prodigamente pelos representantes do povo. A maioria dos políticos brasileiros claramente não se interessa pelo desenvolvimento sustentável em uma sociedade equilibrada. Preferem alimentar o comodismo, a estagnação, sedimentar o mito do governo grátis, promovendo uma inclusão que paradoxalmente exclui.

O projeto de poder objetiva a promoção de reconduções eleitorais sucessivas, quando, na verdade, deveria ser focalizado no indivíduo e no acesso às oportunidades. A prosperidade não virá através de mecanismos ineficientes de redistribuição de renda. Ninguém enriquece por pedir outro talão de cheque. O trabalho dignifica, e a autonomia individual significa liberdade e assegura dignidade.

e a natureza; 9) lazer; 10) controle sobre o próprio ambiente, que engloba tanto a participação política, quanto a capacidade de ter propriedade, de buscar trabalho em igualdade de condições e trabalhar dignamente (NUSSBAUM, Martha. Fronteiras da justiça. São Paulo: Martins Fontes, 2013, p. 92-93).

Revista de Direito Brasileira | São Paulo, SP | v. 17 | n. 7 | p. 306 - 327 | Mai./Ago. 2017 
Deve-se avançar na reflexão sobre o papel normalizador do Estado em busca do desenvolvimento humano. A chamada abordagem das capacidades pode ser uma via adequada para encaminhar essa questão.

\section{REFERÊNCIAS BIBLIOGRÁFICAS}

Accenture. High performance. Delivered. Newsroom main. Four Out of 10 Recent College Grads are Underemployed, New Accenture Research Finds. Written by Nancy Goldstein and Rachel Frey. Disponível em: <https://newsroom.accenture.com/news/four-out-of-10-recent-collegegrads-are-underemployed-new-accenture-research-finds.htm>. Acesso em 08/07/2016.

Agência de Notícias, CNI. Cresce demanda por profissionais formados em cursos técnicos industriais. Disponível em: <http://www.portaldaindustria.com.br/cni/imprensa/2015/07/1,66364/cresce-demanda-porprofissionais-formados-em-cursos-tecnicos-industriais.html>. Acesso em 17/07/2016.

Anuário Brasileiro da Educação Básica de 2016. Disponível em: <http://www.todospelaeducacao.org.br//arquivos/biblioteca/anuario_educacao_2016.pdf>. Acesso em 20/07/2016.

BARROCO, M. L. S. Ética e Serviço Social: Fundamentos ontológicos. $7^{\mathrm{a}}$. ed. São Paulo: Cortez, 2008.

BOBBIO, Norberto. A Era dos Direitos. Rio de Janeiro: Campus, 1992.

. Direito e Estado no Pensamento de Emanuel Kant. Brasília: Editora da Universidade de Brasília, 1992.

BOSCH, Mariano, MELGUIZO, Ángel e PAGÉS, Carmen. Melhores aposentadorias, melhores trabalhos - em direção à cobertura universal na América Latina e no Caribe. Banco Interamericano de Desenvolvimento, 2013. Disponível em:

<http://publications.iadb.org/bitstream/handle/11319/462/Melhores\%20Aposentadorias\%20Melho res\%20Trabalhos.pdf;jsessionid=83355BD29B4DE016B4A7CF023E2668F9? sequence $=4>$. Acesso em: 23/12/2014.

BRASIL. Lei $n^{\circ}$. 10.406, de 10 de janeiro de 2002.

BRASIL. Lei nº 10.836, de 9 de janeiro de 2004.

BRASIL. Lei nº 11.096, de 13 de janeiro de 2005.

BRASIL. Lei $\mathrm{n}^{\circ}$. 12.513, de 26 de outubro de 2011.

BRASIL. Lei no . 12.711, de 29 de agosto de 2012.

CASTRO, Paulo Rabello de. O mito do governo grátis. Rio de Janeiro: Edições de Janeiro, 2014.

DALLARI, Dalmo de Abreu. Elementos de Teoria Geral do Estado. 23a Edição 2002. Editora Saraiva. 
Declaração de Margaret Thatcher sobre tributos. Disponível em: <https://youtu.be/WPrIGhyPSsE>. Acesso em 14/05/2016.

DWORKIN, Ronald. Levando os direitos a sério. São Paulo: Martins Fontes, 2002. p. 350-351.

EcoDebate, Cidadania \& Meio Ambiente. O aumento do desemprego entre as pessoas mais escolarizadas. Artigo de José Eustáquio Diniz Alves. Disponível em: <https://www.ecodebate.com.br/2016/03/18/o-aumento-do-desemprego-entre-as-pessoas-maisescolarizadas-artigo-de-jose-eustaquio-diniz-alves/>. Acesso em 21/07/2016.

Estadão, Gasto com Fies cresce 13 vezes e chega a $R \$ 13,4$ bi, mas ritmo de matrículas cai. Reportagem de José Roberto de Toledo, Paulo Saldaña e Rodrigo Burgarelli. Disponível em: <http://sao-paulo.estadao.com.br/noticias/geral,gasto-com-fies-cresce-13-vezes-e-chega-a-r-13-4bi-mas-ritmo-de-matriculas-cai-imp-, 1634714>. Acesso em 08/07/2016.

Folha de S. Paulo, Auditoria aponta descontrole em vitrine de Dilma. Reportagem de Renata Agostini e Flávia Foreque. Disponível <http://www1.folha.uol.com.br/poder/2014/10/1534748-auditoria-aponta-descontrole-em-vitrinede-dilma.shtml>. Acesso em 17/07/2016.

, Dilma corta metade das vagas no Pronatec, promessa de campanha. Reportagem de Flávia Foreque e Valdo Cruz. Disponível em: <http://www1.folha.uol.com.br/educacao/2015/09/1677647-dilma-corta-metade-das-vagas-nopronatec-promessa-de-campanha.shtml>. Acesso em 17/07/2016.

Quase 50\% dos universitários graduados na China estão desempregados. DA EFE. Disponível em: <http://www1.folha.uol.com.br/mundo/2013/08/1321726-quase-50-dosuniversitarios-graduados-na-china-estao-desempregados.shtml>. Acesso em 20/06/2016.

, Quase metade dos devedores atrasa pagamento do Fies. Reportagem de Flávia Foreque. Disponível em: <http://www1.folha.uol.com.br/educacao/2016/01/1727211-quase-metade-dosdevedores-atrasa-pagamento-do-fies.shtml>. Acesso em 11/07/2016.

RUF: Ranking Universitário Folha 2013. Disponível em:

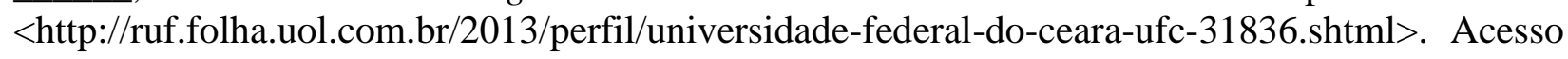
em 17/07/2016.

Folha Política, JusBrasil. Pesquisador conclui que mais da metade dos universitários brasileiros são analfabetos funcionais. Reportagem de Maurício Gieseler. Disponível em: <http://folhapolitica.jusbrasil.com.br/noticias/1 13329087/pesquisador-conclui-que-mais-dametade-dos-universitarios-brasileiros-sao-analfabetos-funcionais $>$. Acesso em 20/07/2016.

Fórum Mundial de Educação 2015. Declaração de Incheon. Educação 2030: rumo a uma educação de qualidade inclusiva e equitativa e à educação ao longo da vida para todos. Disponível em: 〈http://unesdoc.unesco.org/images/0023/002331/233137POR.pdf>. Acesso em 18/03/2017.

Fundo de Financiamento Estudantil. Prestação de Contas Ordinárias Anual, Relatório de Gestão do Exercício de 2014. Secretaria de Educação Superior. Disponívelem:

<http://portal.mec.gov.br/index.php?option=com_docman\&view=download\&alias=17528-fiesrelatorio-gestao-pcoa-exercicio-2014-tcu\&category_slug=maio-2015-pdf\&Itemid=30192> . Acesso em 11/07/2016. 
G1, Globo, Após 5 meses, universidades federais encerram greve a partir desta terça. Disponível em: <http://g1.globo.com/educacao/noticia/2015/10/apos-5-meses-universidades-federaisencerram-greve-partir-desta-terca.html>. Acesso em 16/07/2016.

, Brasil encerra 2014 com menor taxa de desemprego já registrada. Reportagem de Christiane Pelajo. Disponível em: <http://g1.globo.com/jornal-da-globo/noticia/2015/01/brasilencerra-2014-com-menor-taxa-de-desemprego-ja-registrada.html>. Acesso em 06/12/2015. , Gasto do governo com Fies em 2015 já soma 52\% do orçamento previsto. Reportagem de Ana Carolina Moreno. Disponível em: <http:/g1.globo.com/educacao/noticia/2015/07/gastodo-governo-com-fies-em-2015-ja-soma-52-do-orcamento-previsto.html>. Acesso em 11/07/2016. , Professores do Pronatec estão sem remuneração há oito meses em IFMG. Do G1

Centro-Oeste de Minas. Disponível em: <http://g1.globo.com/mg/centrooeste/noticia/2015/07/professores-do-pronatec-estao-sem-remuneracao-ha-oito-meses-emmg.html>. Acesso em 17/07/2016.

GALDINO, Flávio. O custo dos direitos. Artigo integrante da obra: TORRES, Ricardo Lobo (org.). Legitimação dos direitos humanos. Rio de Janeiro: Renovar, 2002.

GIOVANNI, Geraldo Di. Sistemas de proteção Social: uma introdução conceitual. In Reforma do Estado. Políticas de Emprego no Brasil. Campinas, UNICAMP, IE, 1998.

Instituto Atlântico, Movimento Brasil Beneficente, Relatório de Atividades de janeiro a maio de 2014, Pesquisa Nacional Datafolha “Gestão Pública Demandada pelo Cidadão”. Disponível em: $<$ http://acijs.com.br/blog/wpcontent/uploads/2014/06/RELAT\%C3\%93RIO-MBE-2014-JAN-MAIO.pdf>. Acesso em: 28/05/2016.

KERSTENETZKY, Célia Lessa. Redistribuição e desenvolvimento? A Economia Política do Programa Bolsa Família. DADOS - Revista de Ciências Sociais. Rio de Janeiro. v. 52, n. 1, p. 53-83, 2009.

MIGUEL, Luis Felipe. Autonomia, paternalismo e dominação na formação das preferências. OPINIÃO PÚBLICA, Campinas, vol. 21, n 3, dezembro, 2015, p. 601-625. Disponível em: <http://dx.doi.org/10.1590/1807-01912015213601>. Acesso em: 14/05/2016.

Ministério da Educação. Pronatec Bolsa-Formação, Uma Avaliação Inicial sobre Reinserção no Mercado de Trabalho Formal. Disponível em: $<$ http://portal.mec.gov.br/index.php?option=com_docman\&view=download\&alias=22061 24092015-lancamento-estudos-pronatec-ministerio-fazenda-pdf\&category_slug=abril-2010pdf\&Itemid=30192>. Acesso em 17/07/2016.

Ministério da Justiça e Cidadania, Direitos Humanos. Travestis e trans de São Paulo receberão bolsa qualificação. Iniciativa é pioneira na América do Sul. Notícias janeiro de 2015. Disponível em: $\quad<$ http://www.sdh.gov.br/noticias/2015/janeiro/travestis-de-sao-paulo-receberao-bolsaqualificacao.-iniciativa-e-pioneira-na-america-do-sul>. Acesso em 26/07/2016.

Ministério do Desenvolvimento Agrário, Safra Garantia, Sobre o Programa. Disponível em: <http://www.mda.gov.br/sitemda/secretaria/saf-garantia/sobre-o-programa>. Acesso em $10 / 03 / 2016$. 
Ministério do Desenvolvimento Social e Agrário, Bolsa Família, Benefícios. Disponível em: $<$ http://mds.gov.br/assuntos/bolsa-familia/o-que-e/beneficios/beneficios $>. \quad$ Acesso em 10/03/2016.

, Cadastro Único, O que é e para que serve. Disponível em: <http://mds.gov.br/assuntos/cadastro-unico/o-que-e-e-para-que-serve>. Acesso em 10/03/2016.

Ministério do Trabalho e Previdência Social, Bolsa Qualificação. Disponível em: <http://www.mtps.gov.br/seguro-desemprego/modalidades/bolsa-qualificacao $>$. Acesso em $10 / 03 / 2016$.

NOZICK, Robert. Anarquia, Estado e Utopia. Tradução Ruy Jungmann. Rio de Janeiro: Jorge Zahar Editor, 1974, p. 259.

NUSSBAUM, Martha. Fronteiras da justiça. São Paulo: Martins Fontes, 2013.

Observatório da Seca, Bolsa Estiagem. Disponível em:

<http://www.brasil.gov.br/observatoriodaseca/bolsa-estiagem.html >. Acesso em 10/03/2016.

O Globo, Globo, Bolsa Família: mais de 1,6 milhão de casas abriram mão do benefício. Reportagem de Demétrio Weber. Disponível em: <http://oglobo.globo.com/brasil/bolsa-familiamais-de-16-milhao-de-casas-abriram-mao-do-beneficio-8312947>. Acesso em 08/07/2016.

PIKETTY, Thomas. O Capital no Século XXI. Rio de Janeiro: Intrínseca, 2014.

Planeta Educação, conhecimento que transforma. Analfabetismo Funcional. Reportagem de Andréa Cristina Sória Prieto. Disponível em: $<$ http://www.planetaeducacao.com.br/portal/impressao.asp?artigo=700>. Acesso em 20/07/2016.

Portal Brasil, Educação. Fies renova contratos com reajuste acima de 6,4\%. Fonte: Ministério da Educação e Agência Brasil. Disponível em: <http://www.brasil.gov.br/educacao/2015/03/fiesrenova-contratos-com-reajuste-acima-de-6-4>. Acesso em 11/07/2016.

. Aluno universitário custa cinco vezes mais que um estudante da educação básica. Fonte: Agência Brasil. Disponível em: <http://www.brasil.gov.br/educacao/2010/03/aluno-universitariocusta-cinco-vezes-mais-que-um-estudante-da-educacao-basica>. Acesso em 16/07/2016.

Portal PMPA, Catadores começam curso de alfabetização e profissionalização. Texto de Adriano Santana. Edição de Andrea Brasil. Disponível em: <http://www2.portoalegre.rs.gov.br/portal_pmpa_novo/default.php?p_noticia=184820\&CATAD ORES+COMECAM+CURSO+DE+ALFABETIZACAO+E+PROFISSIONALIZACAO>. Acesso em 10/04/2016.

Programa das Nações Unidas para o Desenvolvimento - PNUD, Objetivos de Desenvolvimento do Milênio, Relatório Nacional de Acompanhamento. Brasil, maio de

$$
2014 . \quad \text { Disponível }
$$
em: <http://www.pnud.org.br/Docs/5_RelatorioNacionalAcompanhamentoODM.pdf $>$. Acesso em 20/03/2016.

REIS, João José e SILVA, Eduardo. Negociação e conflito: a resistência negra no Brasil escravista. São Paulo: Editora Schwarcz, 1989. 
Revista Exame, Taxa de desemprego no Brasil deve atingir 10\% em 2016. Reportagem de Ana Carolina Papp e Luiz Guilherme Gerbelli, do Estadão Conteúdo. Disponível em: <http://exame.abril.com.br/economia/noticias/taxa-de- desemprego-no-brasil-deve-atingir-10-em2016>. Acesso em 06/12/2015.

Revista Istoé. Desemprego e manipulações. Reportagem de Ricardo Amorim. Disponível em: $<$ http://www.istoe.com.br/colunas-eblogs/coluna/367223_DESEMPREGO+E+MANIPULACOES >. Acesso em 06/12/2015.

Revista Veja, Abril. Calote bilionário. Reportagem de Lauro Jardim. Disponível em: $<$ http://veja.abril.com.br/blog/radar-on-line/brasil/fies-governo-da-calote-bilionario-emuniversidades/>. Acesso em 11/07/2016.

ROCASOLANO, Maria Méndez. El poder del conocimiento em tempos de crisis: la educación de ciudadanos frente al conocimiento de los individuos, revisión de la paideia Isocrática. Disponível em: <https://www.academia.edu/7795265/EL_PODER_DEL_CONOCIMIENTO_EN_TIEMPOS_D E_CRISIS_LA_EDUCACI\%C3\%93N_DE_CIUDADANOS_FRENTE_AL_CONOCIMIENTO _DE_LOS_INDIVIDUOS_REVISI\%C3\%93N_DE_LA_PAIDEIA_ISOCR\%C3\%81TICA>. Acesso em 18/03/2017.

SEN, Amartya. A ideia de justiça. São Paulo: Companhia das Letras, 2011.

SILVA, M. O. da S.; YASBEK, M. C.; GIOVANNI, G. di. A Política Social Brasileira no Século XXI: a prevalência dos programas de transferência de renda. São Paulo: Cortez, 2004.

SILVEIRA, Antônio Maria. Redistribuição de renda. R. Bras. Econ. Rio de Janeiro, 29 (2): 11 15, abril/jun. 1975.

Syllabus. Opinion of the Court. Supreme Court of the United States. No. 14-981. Abigail Noel Fisher, Petitioner v. University of Texas at Austin et al. Disponível em: <https://www.supremecourt.gov/opinions/15pdf/14-981_4g15.pdf>. Acesso em 16/07/2016.

Supremo Tribunal Federal. ADPF (Arguição de Descumprimento de Preceito Fundamental) 186. Ministro Relator: Ricardo Lewandowski. 26/04/2012. Plenário. Inteiro teor. Disponível em: $<$ http://redir.stf.jus.br/paginadorpub/paginador.jsp?docTP=TP\&docID=6984693>. Acesso em 16/07/2016.

TELLES, V. da S. Pobreza e cidadania. São Paulo: Editora 34; 2001.

WENCZENOVICZ, Thaís Janaína; PAIM, Robson Olivino. Olhares ao campo: educação, história $e$ desenvolvimento. Disponível em: <https://books.google.com.br/books?id=jkFxCwAAQBAJ\&pg=PT190\&lpg=PT190\&dq=primeir $\mathrm{a}+\mathrm{le}+\mathrm{a}+$ prever $+\mathrm{o}+$ sistema $+\mathrm{de}+$ cotas + rio $+\mathrm{de}+$ janeiro\&source $=\mathrm{bl} \& o t s=S P V T Q J f v w 5 \& \operatorname{sig}=\mathrm{wYq}$ 6dv6Gd5zHpvE3Fhrkh86C3t0\&hl=pt-

BR\&sa $=X \& v e d=0 a h U K E w i D k e C 9 i \_j A h W K i p A K H S d u B y Y Q 6 A E I J D A B \# v=$ onepage\&q=3.7 $08 \& \mathrm{f}=$ false $>$. Acesso em 16/07/2016. 